\title{
Comparison of DLK incidence after laser in situ keratomileusis associated with two femtosecond lasers: Femto LDV and IntraLase FS60
}

This article was published in the following Dove Press journal:

Clinical Ophthalmology

6 July 2013

Number of times this article has been viewed

\author{
Minoru Tomita ${ }^{1-3}$ \\ Yuko Sotoyama' \\ Satoshi Yukawa' \\ Tadayuki Nakamura' \\ 'Shinagawa LASIK Center, \\ Chiyoda-ku, Tokyo, Japan; \\ ${ }^{2}$ Department of Ophthalmology, \\ Wenzhou Medical College, Wenzhou, \\ People's Republic of China; ${ }^{3}$ Eye Can \\ Cataract Surgery Center, Manila, \\ Philippines
}

Purpose: To compare the incidence of diffuse lamellar keratitis (DLK) after laser in situ keratomileusis (LASIK) with flap creation using the Femto LDV and IntraLase ${ }^{\text {TM }}$ FS60 femtosecond lasers.

Methods: A total of 818 consecutive myopic eyes had LASIK performed using either Femto LDV or IntraLase FS60 for flap creation. The same excimer laser, the Allegretto Wave ${ }^{\circledR}$ Eye-Q Laser, was used for correcting refractive errors for all patients. In the preoperative examination, uncorrected distance visual acuity, corrected distance visual acuity, and manifest refraction spherical equivalent were measured. At the postop examination, the same examinations were performed along with a slit-lamp biomicroscopic examination, and patients with DLK were classified into stages. For the statistical analysis of the DLK occurrence rate and the visual and refractive outcomes, the Mann-Whitney's $U$-test was used.

Results: In the Femto LDV group with 514 eyes, 42 (8.17\%) had DLK. In the IntraLase FS60 group with 304 eyes, $114(37.5 \%)$ had DLK. There was a statistically significant difference in the DLK incidence rate between these groups $(P<0.0001)$. Both groups had excellent visual and refractive outcomes. Although low levels of DLK were observed for both groups, they did not affect visual acuity.

Conclusion: While there were significantly fewer incidences of low level DLK when using Femto LDV, neither femtosecond laser induced high levels of DLK, and any postoperative DLK cleared up within 1 week. Therefore, both lasers provide excellent results, with no clinical differences, and both excel at flap creation for LASIK.

Keywords: LASIK, Ziemer, Femto LDV, DLK, IntraLase FS60, femtosecond laser

\section{Introduction}

For many years, laser assisted in situ keratomileusis surgery (LASIK) has been widely accepted as a procedure to correct visual errors. Since the first femtosecond laser was introduced in 2002, all-laser LASIK using a femtosecond laser has been gaining popularity. The clinical safety and benefits of femtosecond lasers for corneal flap creation have been reported, including; predictable flap thicknesses, better astigmatic neutrality, and decreased epithelial injuries, when compared with mechanical microckeratomes. ${ }^{1}$ The use of femtosecond lasers has become more common with the recent release of five femtosecond laser systems: the IntraLase ${ }^{\text {TM }}$ FS (Abbot Medical Optics, Inc, Santa Ana, CA, USA); Femtec ${ }^{\circledR}$ (20/10 PerfectVision Optische Gerate GmbH, Heidelberg, Germany); VisuMax ${ }^{\circledR}$ femtosecond laser system (Carl Zeiss Meditec, Jena, Germany); Femto LDV (Ziemer Ophthalmic Systems AG, Port, Switzerland); and the WaveLight ${ }^{\circledR}$ FS200 Femtosecond Laser (Alcon Laboratories Inc, Fort Worth, TX, USA).
Correspondence: Minoru Tomita Shinagawa LASIK Center, Yurakucho ITOCiA I4F, 2-7-I Yurakucho, Chiyoda-ku, Tokyo, 100-0006, Japan Tel +81352218137

Fax +8I3522I3138

Email tomita@shinagawa-lasik.com 
At our clinic, we currently use both the IntraLase FS60 and Femto LDV.

Diffuse lamellar keratitis (DLK) is a sterile inflammation underneath the flap, known as one of the complications after LASIK surgery. ${ }^{2}$ DLK is characterized by a diffuse, white, granular infiltrate that appears within a few days after LASIK surgery. ${ }^{2}$ The etiology of DLK is still unknown; however, it seems to have multiple causes, such as povidone-iodine solutions, hemorrhage, carboxymethylcellulose drops, bacterial endotoxins, epithelial defects caused by the surgery, debris from the microkeratome blade, atopy, marking pens, toxic chemicals, meibomian secretions, and traumatic flap dislocation or subsequent surgical repair. ${ }^{2-12}$ Patients with DLK may claim other symptoms, such as irritation, blurred vision, pain, or sensitivity to light. However, some patients do not experience any symptoms in the early stages. When the symptoms of DLK are recognized, immediate treatment is necessary in order to prevent its progression. Worsening cases may lead to scarring, stromal melt, haze, hyperopic shift, irregular astigmatism, or permanent visual loss. ${ }^{13}$ DLK is usually self-limiting or treated with topical medications, such as steroids, in its early stages. For severe cases, flap lifting and irrigation are needed. ${ }^{13}$

Although there are numerous studies of DLK caused by mechanical microkeratomes, there are only a few reports of DLK incidence caused by femtosecond lasers. Furthermore, we found no reports comparing the incidence of DLK between femtosecond lasers. In this study, we classified patients with DLK into five stages and compared two femtosecond lasers, the Femto LDV and the IntraLase FS60, which are different in terms of their laser system specification, for the incidence of DLK. We also focused on examining the preoperative and postoperative visual acuity and evaluated whether DLK incidence would affect visual acuity after LASIK surgery.

\section{Patients and methods}

\section{Study design}

In this prospective study, 818 consecutive eyes of 409 patients that had LASIK using Femto LDV or IntraLase FS60, at Shinagawa LASIK Center, Tokyo, Japan in July 2010 were studied. During the period, 514 eyes of 257 patients (101 men and 156 women) with a mean age of 31.40 years \pm 6.95 (range: 18 to 59 years) had bilateral LASIK with the Ziemer Femto LDV (the Femto LDV group), while 304 eyes of 152 patients (100 men and 52 women) with a mean age of 30.61 years \pm 7.05 (range: 18 to 54 years) had bilateral LASIK with IntraLase FS60 (the IntraLase FS60 group).
All the surgical and pre/postoperative procedures were thoroughly explained to all participating patients and the patients provided written, informed consent before undergoing the procedure.

\section{Preoperative examinations}

All patients had a complete preoperative ophthalmologic examination that included uncorrected distance visual acuity (UDVA), corrected distance visual acuity (CDVA), manifest refraction spherical equivalent (MRSE), keratometry; (ARK-530A; NIDEK Co Ltd, Gamagori, Japan), corneal topography (TMS-4; Tomey Corp, Nagoya, Japan), specular microscopy; (Noncon ROBO FA-3509 ${ }^{\circledR}$; Konan Medical Inc, Hyogo, Japan), wavefront analysis (KR-9000PW; Topcon Corp, Tokyo, Japan), measurement of the pupil before and after mydriasis, higher order aberration (OPD-Scan II; NIDEK Co Ltd), anterior eye segment (Pentacam ${ }^{\circledR}$; Oculus Optikgeriite $\mathrm{GmbH}$, Wetzlar, Germany), corneal thickness (Contact pachymeter SP-3000; Tomey Corp), and slitlamp biomicroscopy (Carl Zeiss Meditec, Jena, Germany). When we noted irregular corneal topography during the Pentacam ${ }^{\circledR}$ and TMS-4 examinations, an Orbscan ${ }^{\circledR}$ (Bausch and Lomb Inc, Rochester, NY, USA) image was obtained for additional evaluation. LASIK was not performed for patients with keratoconus or an insufficient residual bed depth (of less than $300 \mu \mathrm{m}$ ) after preoperative examination.

\section{Surgical technique}

The corneal flap was created using one of two femtosecond lasers. The raster energy and side-cut energy were set at $100 \mathrm{~nJ}$ for the Femto LDV. For the IntraLase FS60, a bed energy level of $1.0 \mu \mathrm{J}$, and a side-cut energy level of $0.80 \mu \mathrm{J}$ were set. After the flap was created with either laser, the flap was lifted and excimer laser ablation was performed using the wavefront optimized Allegretto Wave Eye-Q $400 \mathrm{~Hz}$ (Alcon Laboratories Inc, Fort Worth, TX, USA).

\section{Postoperative examinations}

Follow-up visits were scheduled at 1 day, 1 week, and 3 months postsurgery. Postoperative examinations included UDVA, CDVA, and MRSE. A slit-lamp biomicroscopic examination of the corneal flap and anterior segment of the patient's eyes was also carried out. On the day of surgery, a complete set of medications was given to all patients. Patients used dexamethasone sodium m-sulfobenzoate 0.1\% (DEX Ophthalmic Solution 0.1\%; Nitto Medic Co Ltd, Toyama, Japan) once every hour, moxifloxacin hydrochloride $0.5 \%$ (VIGAMOX ${ }^{\circledR}$; Alcon Laboratories Inc.) once every hour, then 
sodium hyaluronate $0.1 \%$ (Hyalonsan Ophthalmic Solution $0.1 \%$; Nitto Medic Co Ltd) once every hour, and oxybuprocaine hydrochloride (BENOXYL; Santen Pharmaceutical Co Ltd, Osaka, Japan) for pain, if needed. The day after surgery, patients used dexamethasone sodium m-sulfobenzoate $0.1 \%$ five times a day, moxifloxacin hydrochloride $0.5 \%$ five times a day, and sodium hyaluronate $0.1 \%$ five times a day. The regimen of all eye drops was finished after 1 week.

At their day-1 postoperative follow-up visit, patients were divided into four stages according to the widely known DLK classification system. ${ }^{13}$ The system was based on the extent of centripetal migration of any inflammatory cells. In the first stage of DLK, white granular cells appear at the laminar flap edge or hinge (stage 1). At stage 2, the visual axis is involved as the white granular cells develop at the center of the flap. At stage 3, the inflammation has progressed and spread over the flap, and there is an aggregation of denser white cells clumped over the visual axis. At stage 4, severe inflammation has resulted in collagenase release, stromal melt, and permanent scarring, associated with visual loss. ${ }^{13}$ In addition, we have adopted a method to divide stage 1 into two substages; stage 1a and stage $1 \mathrm{~b}$, in order to define any postoperative DLK more precisely (Figure 1). At stage 1a, DLK is barely seen on the peripheral part of the flap, whereas at stage $1 b$, any DLK is confined to the flap edge.

When DLK was diagnosed in our clinic, immediate treatment was provided, and frequent follow-ups were scheduled to prevent further progression. The treatment procedure for DLK varied by stage. Frequent use of a topical steroid drop (dexamethasone sodium m-sulfobenzoate $0.1 \%$ ) was required five times a day for patients with stage 1 , and every hour for patients with stage 2 . However, if their symptoms were close to stage 3 or if the potential risk for developing stage 3 was expected, flap irrigation was considered in order to prevent the development of stage 3 and/or 4 . For patients with stage 3 and/or 4 DLK, it was necessary to lift the flap and rinse the bed and the interface of the flap with a balanced salt solution (Otsuka Pharmaceutical Co Ltd, Tokyo, Japan) and a topical steroid. For patients with stage 2 or more, systemic medication (H2 blocker and prednisolone $30 \mathrm{mg}$ per day) was prescribed for

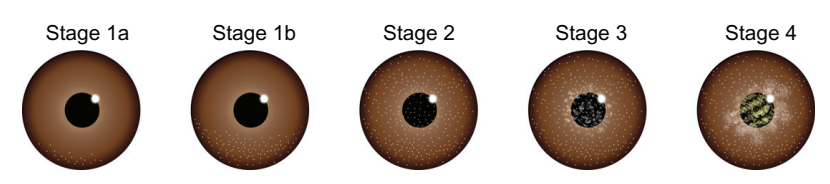

Figure I Grading classification system for DLK. Notes: DLK occurrences in our clinic were classified into stages. Abbreviation: DLK, diffuse lamellar keratitis.
3 days. In this study, patients without any symptoms of DLK were classified as stage 0 .

\section{Statistical analysis}

The data was analyzed with statistical software; StatView J 5.0; (Abacus Concepts, Inc, Piscataway, NJ, USA). The Mann-Whitney $U$-test was used to evaluate the statistical significance of the DLK incidence of each stage associated with these two femtosecond lasers, and also to evaluate the visual and refractive outcomes of patients with or without DLK.

\section{Results}

All 409 patients (818 eyes) completed their scheduled day-1 postoperative follow-up visit, while 353 patients (706 eyes) returned for their week-1 postoperative examination, and 132 patients (264 eyes) returned for their 3-month postoperative examination. The patients who didn't return to our clinic had postoperative examinations at affiliated clinics.

Table 1 and Figure 2 demonstrate the percentages of DLK incidence for both groups. At postoperative day 1, in the Femto LDV group (totaling 514 eyes), DLK was found in $42(8.17 \%)$ of the eyes, by slit-lamp examination; of these, 35 eyes $(6.81 \%)$ developed stage 1a and seven eyes $(1.36 \%)$ developed stage $1 \mathrm{~b}$. None of the eyes were diagnosed as stage 2,3 , or 4 . The number of eyes with no DLK was $472(91.83 \%)$ in the LDV group. In IntraLase FS60 group (totaling 304 eyes), 114 (37.5\%) of the eyes had DLK; of these, 96 eyes $(31.58 \%)$ developed stage 1a and 18 eyes $(5.92 \%)$ developed stage $1 \mathrm{~b}$. In this group as well, none of the eyes had DLK stage 2, 3, or 4. As a consequence, 190 eyes (62.5\%) did not have DLK in IntraLase FS60 group. The DLK incidence rate was $8.17 \%$ in the Femto LDV group and was $37.5 \%$ in the IntraLase FS60 group. There were significant differences observed between these two femtosecond lasers when the occurrence of DLK was compared at stage 1a and $1 \mathrm{~b}$, at postoperative day 1 ( $P<0.0001$ [Mann-Whitney's $U$-test]).

Dexamethasone sodium m-sulfobenzoate $0.1 \%$, five times a day, was provided to the patients with DLK stage 1a and 1b. At 1 week postop, DLK was no longer found in either group.

The UDVA, CDVA, and MRSE were also examined, preoperatively and at 1 day, 1 week, and 3 months postop. Table 2 demonstrates that the visual and refractive outcomes of this study were excellent in both groups. The safety index (mean postoperative CDVA divided by mean preoperative CDVA) at 1 day, 1 week, and 3 months postop was 0.97, 1.04, and 1.05, respectively in the Femto LDV group and was 0.99 , 1.06, and 
Table I DLK incidence in LASIK surgery with the femtosecond laser

\begin{tabular}{llllllll}
\hline & $\begin{array}{l}\text { No Eyes } \\
(\mathbf{n}, \%)\end{array}$ & $\begin{array}{l}\text { Stage } \mathbf{0} \\
(\mathbf{n}, \%)\end{array}$ & $\begin{array}{l}\text { Stage Ia } \\
(\mathbf{n}, \%)\end{array}$ & $\begin{array}{l}\text { Stage Ib } \\
(\mathbf{n}, \%)\end{array}$ & $\begin{array}{l}\text { Stage 2 } \\
(\mathbf{n}, \%)\end{array}$ & $\begin{array}{l}\text { Stage 3 } \\
(\mathbf{n}, \%)\end{array}$ & $\begin{array}{l}\text { Stage 4 } \\
(\mathbf{n}, \%)\end{array}$ \\
\hline Femto LDV & $514(100)$ & $472(91.83)$ & $35(6.8 I)$ & $7(1.36)$ & None & $\begin{array}{l}\text { None } \\
\text { None }\end{array}$ & $\begin{array}{l}\text { None } \\
\text { IntraLase FS60 }\end{array}$ \\
\hline
\end{tabular}

Abbreviations: DLK, diffuse lamellar keratitis; LASIK, laser in situ keratomileusis.

1.08 (at 1 day, 1 week, and 3 months postop) in the IntraLase FS60 group. The efficacy index (mean postoperative UDVA divided by mean preoperative CDVA) at 1 day, 1 week, and 3 months postop was $0.95,1.01$, and 1.02 , respectively in the Femto LDV group and was $0.95,1.03$, and 1.04 , respectively in the IntraLase FS60 group.

Additionally, to evaluate whether the DLK incidence affected the visual outcomes, the UDVA, CDVA, and MRSE for patients with DLK stage 0 and stage 1 were also statistically analyzed (Table 3): patients who didn't have DLK symptoms were classified as stage 0 ; whereas patients with DLK stage 1a and/or $1 \mathrm{~b}$ were classified as stage 1 . For the Femto LDV group, there were no significant differences between stages 0 and 1 at any preoperative and postoperative day. However, for the IntraLase group, significant differences were found between the two stages in regards to the CDVA preoperatively, and UDVA and CDVA at postoperative day 1 and week 1 . When comparing the visual outcomes between the DLK and non-DLK groups for both femtosecond lasers, significant differences were observed only the for IntraLase group at certain postoperative days. There were no significant differences seen for LDV group. However, as the visual and refractive results for both femtosecond laser groups were very good, these groups were not clinically different. Moreover, the results of this analysis indicated that the occurrence of stage 1 DLK did not affect visual acuity.

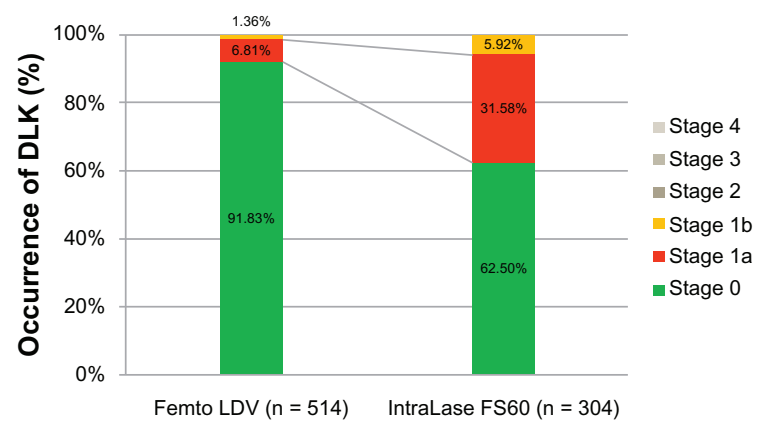

Figure 2 Occurrence of DLK on postoperative day I.

Notes: In the Femto LDV group of 514 eyes, $91.83 \%$ showed no DLK, a lower occurrence rate of DLK stage I compared with the IntraLase ${ }^{\mathrm{TM}}$ FS60 group. No stage 2, 3, or 4 DLK was found in either group.

Abbreviation: DLK, diffuse lamellar keratitis.

\section{Discussion}

The safety and effectiveness of flap creation using a mechanical microkeratome and femtosecond lasers have been reported. ${ }^{14}$ Microkeratomes used to be the primary means for flap creation in LASIK surgery. However, the femtosecond laser is currently taking over that role and is becoming more common.

In particular, one of the distinctive differences between the femtosecond laser and the microkeratome is the precision with which the flap is created. ${ }^{15}$ Several studies have found that femtosecond lasers can create more predictable ${ }^{1,15}$ and smoother flaps than most mechanical microkeratomes. ${ }^{16}$ With the microkeratome, there is an inclination to have a disparity in the thickness when comparing the central and peripheral areas. ${ }^{15}$ Of special note, one study comparing the microkeratome with three femtosecond lasers - the IntraLase,

Table 2 Visual and refractive outcomes of 818 eyes that underwent LASIK with the Femto LDV or IntraLase ${ }^{\mathrm{TM}}$ FS60

\begin{tabular}{lll}
\hline & Femto LDV & IntraLase \\
& & FS60 \\
\hline Preoperative & & \\
$\quad$ Eyes & 514 & 304 \\
Mean UDVA (logMAR) \pm SD & $1.19 \pm 0.29$ & $1.12 \pm 0.29$ \\
Mean CDVA (logMAR) \pm SD & $-0.17 \pm 0.06$ & $-0.18 \pm 0.07$ \\
Mean MRSE (D) \pm SD & $-5.28 \pm 2.86$ & $-4.39 \pm 2.26$ \\
Postoperative I day & & \\
Eyes & 514 & 304 \\
Mean UDVA (logMAR) \pm SD & $-0.15 \pm 0.08$ & $-0.16 \pm 0.11$ \\
Mean CDVA (logMAR) \pm SD & $-0.16 \pm 0.08$ & $-0.18 \pm 0.09$ \\
Mean MRSE (D) \pm SD & $0.17 \pm 0.30$ & $0.14 \pm 0.29$ \\
Postoperative I week & & \\
Eyes & 464 & 242 \\
Mean UDVA (logMAR) \pm SD & $-0.18 \pm 0.07$ & $-0.19 \pm 0.08$ \\
Mean CDVA (logMAR) \pm SD & $-0.19 \pm 0.06$ & $-0.20 \pm 0.07$ \\
Mean MRSE (D) \pm SD & $0.15 \pm 0.28$ & $0.10 \pm 0.24$ \\
Postoperative 3 months & & \\
Eyes & 194 & 70 \\
Mean UDVA (logMAR) $\pm S D$ & $-0.18 \pm 0.08$ & $-0.20 \pm 0.07$ \\
Mean CDVA (logMAR) $\pm S D$ & $-0.19 \pm 0.06$ & $-0.21 \pm 0.06$ \\
Mean MRSE (D) \pm SD & $0.09 \pm 0.35$ & $0.07 \pm 0.22$ \\
\hline Ab & &
\end{tabular}

Abbreviations: CDVA, corrected distance visual acuity; LASIK, laser in situ keratomileusis; MRSE, manifest refraction spherical equivalent; SD, standard deviation; UDVA, uncorrected distance visual acuity; logMAR, logarithm of the Minimum Angle of Resolution; D, diopter. 
Table 3 Visual and refractive outcomes of eyes comparing DLK stage 0 and I for the Femto LDV and IntraLase ${ }^{\text {TM }}$ FS60

\begin{tabular}{|c|c|c|c|c|c|c|}
\hline & \multicolumn{3}{|c|}{ Femto LDV group } & \multicolumn{3}{|c|}{ IntraLase FS60 group } \\
\hline & Stage 0 & Stage I & $P$-value* & Stage 0 & Stage I & $P$-value* \\
\hline \multicolumn{7}{|l|}{ Preoperative } \\
\hline Eyes & 472 & 42 & - & 190 & 114 & - \\
\hline Mean UDVA (logMAR) $\pm S D$ & $1.19 \pm 0.29$ & $1.28 \pm 0.33$ & 0.0911 & $1.14 \pm 0.29$ & $1.08 \pm 0.29$ & 0.1106 \\
\hline Mean CDVA $(\log M A R) \pm S D$ & $-0.17 \pm 0.06$ & $-0.18 \pm 0.06$ & 0.2893 & $-0.17 \pm 0.08$ & $-0.19 \pm 0.05$ & $0.0116^{\dagger}$ \\
\hline Mean MRSE (D) \pm SD & $-5.20 \pm 2.82$ & $-6.18 \pm 3.22$ & 0.0630 & $-4.50 \pm 2.39$ & $-4.19 \pm 2.01$ & 0.3218 \\
\hline \multicolumn{7}{|l|}{ Postoperative day I } \\
\hline Eyes & 472 & 42 & - & 190 & 114 & - \\
\hline Mean UDVA (logMAR) $\pm S D$ & $-0.15 \pm 0.08$ & $-0.16 \pm 0.07$ & 0.8300 & $-0.15 \pm 0.12$ & $-0.18 \pm 0.09$ & $0.0103^{\dagger}$ \\
\hline Mean CDVA $(\log M A R) \pm S D$ & $-0.16 \pm 0.08$ & $-0.18 \pm 0.06$ & 0.1529 & $-0.17 \pm 0.10$ & $-0.19 \pm 0.07$ & $0.0406^{\dagger}$ \\
\hline Mean MRSE (D) \pm SD & $0.16 \pm 0.29$ & $0.20 \pm 0.33$ & 0.6234 & $0.16 \pm 0.32$ & $0.11 \pm 0.22$ & 0.2080 \\
\hline \multicolumn{7}{|l|}{ Postoperative week I } \\
\hline Eyes & 424 & 40 & - & 144 & 98 & - \\
\hline Mean UDVA (logMAR) $\pm S D$ & $-0.18 \pm 0.07$ & $-0.18 \pm 0.07$ & 0.8725 & $-0.18 \pm 0.07$ & $-0.21 \pm 0.08$ & $0.0123^{\dagger}$ \\
\hline Mean CDVA (logMAR) $\pm S D$ & $-0.19 \pm 0.06$ & $-0.18 \pm 0.07$ & 0.3633 & $-0.20 \pm 0.07$ & $-0.22 \pm 0.07$ & $0.0188^{+}$ \\
\hline Mean MRSE (D) \pm SD & $0.14 \pm 0.28$ & $0.21 \pm 0.30$ & 0.1241 & $0.12 \pm 0.25$ & $0.07 \pm 0.22$ & 0.1437 \\
\hline \multicolumn{7}{|l|}{ Postoperative 3 Months } \\
\hline Eyes & 178 & 16 & - & 44 & 26 & - \\
\hline Mean UDVA $(\log M A R) \pm S D$ & $-0.18 \pm 0.08$ & $-0.18 \pm 0.07$ & 0.6937 & $-0.20 \pm 0.06$ & $-0.21 \pm 0.08$ & 0.2614 \\
\hline Mean CDVA (logMAR) $\pm S D$ & $-0.19 \pm 0.07$ & $-0.21 \pm 0.06$ & 0.3597 & $-0.21 \pm 0.05$ & $-0.23 \pm 0.07$ & 0.3090 \\
\hline Mean MRSE (D) \pm SD & $0.09 \pm 0.35$ & $0.02 \pm 0.27$ & 0.1222 & $0.09 \pm 0.23$ & $0.04 \pm 0.21$ & 0.6670 \\
\hline
\end{tabular}

Notes: *Stage 0 versus Stage I ( la + lb); † statistically significant by Mann-Whitney U-test $(P<0.05)$.

Abbreviations: CDVA, corrected distance visual acuity; DLK, diffuse lamellar keratitis; MRSE, manifest refraction spherical equivalent; SD, standard deviation; UDVA, uncorrected distance visual acuity; logMAR, logarithm of the Minimum Angle of Resolution; D, diopter.

VisuMax, and Femto LDV - reported that the Femto LDV system was the most predictable with respect to flap thickness (intended versus measured). ${ }^{15}$

In regard to complications caused by the microkeratome and/or femtosecond laser, microkeratomes induced significantly more epithelial defects, such as buttonholes or decentered flaps, intraoperatively while femtosecond lasers had significantly higher incidences of gas breakthrough and postoperative DLK. ${ }^{17,18}$ The eyes with femtosecond-created flaps had a lower incidence of dry eye than the ones with microkeratome-created flaps. ${ }^{19}$ Suction loss, which induces buttonholes and incomplete flaps, was reported when using a microkeratome..$^{20}$ In the case of suction loss, immediate reattempts to cut the flap using femtosecond lasers after intraoperative suction loss did not affect the visual acuities or the refractive outcomes. ${ }^{21}$

Regarding visual and refractive outcomes of LASIK surgery, significantly better postoperative UCVA and manifest refractive results were reported with femtosecond lasers. ${ }^{22}$ From previous studies, the femtosecond laser is generally considered to be superior to the microkeratome. ${ }^{15,16,19,22}$

The effect of the energy level used by femtosecond lasers on tissue has been investigated in previous studies. The effects on the corneal stromal cells by different femtosecond laser energy levels were analyzed, and researchers found that higher energy levels triggered greater cell death. ${ }^{23}$ Moreover, greater inflammatory cell infiltration in the cornea has been observed with higher femtosecond laser energy levels. ${ }^{23}$ The possibility that lower-energy femtosecond lasers induce less tissue damage and inflammation was considered. Other LASIK complications, such as rainbow glare and transient light sensitivity, are also considered to be caused by femtosecond lasers. ${ }^{24,25}$ Those studies indicate that lower pulse energy is one of the key parameters to reduce complication rates.

DLK is defined as the formation of noninfectious corneal interlamellar inflammation. ${ }^{2}$ According to the literature, there are two major factors that induce inflammation during corneal flap creation using femtosecond lasers. ${ }^{23}$ One of the factors is that direct energy ablation by the femtosecond laser increases the number of necrotized cells in the stroma. ${ }^{23}$ Femtosecond laser-assisted flap creation is likely to contribute to greater inflammation, especially since higher energy levels result in greater stromal cell death. ${ }^{23}$ Additionally, the other study reported that lower side-cut and angle energy eliminated the interface inflammation and also reported that use of higher laser energies during flap creation caused greater damage. ${ }^{26}$ Applying this remarkable clinical experience to our study, the lower pulse energy level of the LDV system could have resulted in reduced stromal cell death and inflammation, and 
we hypothesize that the incidence of DLK may have been related to the energy level of the femtosecond laser.

The Femto LDV has different technical characteristics that distinguish it from conventional femtosecond lasers, such as the IntraLase FS60. The fundamental differences are the beam delivery and cutting process. ${ }^{27} \mathrm{~A}$ comparison of the technical features of these two femtosecond lasers is described in Table 4. The IntraLase FS60 is characterized as having a high pulse energy and low pulse frequency, as it delivers pulse energies in the order of $1 \mu \mathrm{J}$, with a repetition rate of $60 \mathrm{kHz}$. On the other hand, the Femto LDV creates a corneal flap with a $1,000 \mathrm{kHz}$ pulse rate and uses pulse energy levels in the nanojoule range. In this study, a $1 \mu \mathrm{J}$ mean raster energy and $0.8 \mu \mathrm{J}$ mean side-cut energy were used in the IntraLase system, and $100 \mathrm{~nJ}$ energy was used by the Femto LDV to create the stromal bed and side cut. These differences in system parameters affect the nature of the process. ${ }^{27}$

The low pulse energies of the Femto LDV produce small and tightly overlapped dissection spots. This overlapped beam delivery makes a stromal flap cut without tissue bridges, and thus, the flap dissection is completed easily, with minimum damage to the corneal tissue. ${ }^{27}$ On the other hand, spots from IntraLase lasers do not overlap during the photodisruption process. Thus two adjoining laser spots can be distant from each other, ${ }^{27}$ which leads to tissue bridges or uncut areas on the cornea, and this can create traction forces caused by dissection of the corneal lamellar, when using a blunt instrument to lift the flap.

Table 4 Comparison of the technical features of the Femto LDV and IntraLase ${ }^{\mathrm{TM}} \mathrm{FS} 60$

\begin{tabular}{|c|c|c|}
\hline & $\begin{array}{l}\text { Femto LDV with } \\
\text { top view camera }\end{array}$ & IntraLase FS60 \\
\hline Manufacturer & $\begin{array}{l}\text { Ziemer Group AG, } \\
\text { Port, Switzerland }\end{array}$ & $\begin{array}{l}\text { Abbott Medical } \\
\text { Optics Inc, CA, USA }\end{array}$ \\
\hline Concept & Oscillator & Amplifier \\
\hline $\begin{array}{l}\text { Flap creating } \\
\text { method }\end{array}$ & Flattened cornea & Flattened cornea \\
\hline Wavelength & $1040 \mathrm{~nm}$ & $1040 \mathrm{~nm}$ \\
\hline Engine & $>1 \mathrm{MHz}$ & $60 \mathrm{kHz}$ \\
\hline Pulse width (fs) & 250 & $>500$ \\
\hline Spot size $(\mu \mathrm{m})$ & $<1$ & $>1$ \\
\hline Pulse energy & nJ range & $>I \mu J$ \\
\hline Surface quality & Excellent & Excellent \\
\hline Size & Very small & Bulky \\
\hline Mobility & Mobile & Fixed \\
\hline $\begin{array}{l}\text { Environmental } \\
\text { requirements }\end{array}$ & $\begin{array}{l}\text { Room temperature/ } \\
\text { not sensitive to } \\
\text { environment }\end{array}$ & $\begin{array}{l}\text { Constant temperature/ } \\
\text { humidity }\end{array}$ \\
\hline
\end{tabular}

Note: Republished with permission of SLACK Incorporated, from Evaluation of LASIK Treatment with the Femto LDV in patients with corneal opacity, Tomita M, Chiba A, Matsuda J and Nawa Y, 28(I):25-30, 20I3; permission conveyed through Copyright Clearance Center, Inc.
Several articles have proved the superiority of the Femto LDV and the IntraLase, so there are advantages to using these femtosecond lasers for LASIK surgery. A study reported that flap dimensions and refractive results of LASIK using the Femto LDV were predictable, with an acceptable rate of complications and that no eyes had significant losses in CDVA at 6 months postop. ${ }^{28}$ Likewise, the predictability and accuracy of the IntraLase for flap creation, when compared to a microkeratome, were reported. ${ }^{29}$ In our previous studies, use of the Femto LDV and IntraLase FS60 were evaluated in the LASIK treatments of patients with corneal opacity. ${ }^{30}$ Although these lasers do not have clinically significant differences in terms of visual outcomes, using the Femto LDV, with its lower pulse energy, on areas of corneal opacity creates less gas, which reduces the chance of gas breakthrough in the subepithelial tissue. ${ }^{30}$

In our study analyzing the incidence of DLK following the use of these two lasers, we showed that the Femto LDV induced significantly lower rates at postoperative day 1. The possible advantage of LDV is the lower incidence rate for postoperative DLK. However, no DLK of stage 2 or higher was found in either LDV or IntraLase groups at postoperative day 1. After using the steroid drops for 1 week, all DLK presence disappeared. Additionally, both lasers resulted in excellent refractive outcomes. The clinical results of our experiment confirm that both the Femto LDV and IntraLase FS60 were effective surgical tools for LASIK surgery.

\section{Conclusion}

Consistent with previous studies, ${ }^{1,15,29}$ our findings indicate that both femtosecond lasers excel at LASIK flap creation. In terms of DLK incidence, the Femto LDV was significantly lower than IntraLase FS60. However, both lasers were excellent, and no clinical differences were found between them since both femtosecond lasers did not induce DLK stage 2 or higher, and any DLK presences cleared within 1 week.

\section{Disclosure}

Dr Tomita is a consultant for Ziemer Ophthalmic Systems AG, SCHWIND Eye-Tech-Solutions, and AcuFocus Inc. The authors report no other conflicts of interest in this work.

\section{References}

1. Kezirian GM, Stonecipher KG. Comparison of the IntraLase femtosecond laser and mechanical keratomes for laser in situ keratomileusis. $J$ Cataract Refract Surg. 2004;30(4):804-811.

2. Smith RJ, Maloney RK. Diffuse lamellar keratitis. A new syndrome in lamellar refractive surgery. Ophthalmology. 1998;105(9): $1721-1726$. 
3. MacRae S, Macaluso DC, Rich LF. Sterile interface keratitis associated with micropannus hemorrhage after laser in situ keratomileusis. J Cataract Refract Surg. 1999;25(12):1679-1681.

4. Samuel MA, Kaufman SC, Ahee JA, Wee C, Bogorad D. Diffuse lamellar keratitis associated with carboxymethylcellulose sodium 1\% after laser in situ keratomileusis. J Cataract Refract Surg. 2002;28(8):1409-1411.

5. Holland SP, Mathias RG, Morck DW, Chiu J, Slade SG. Diffuse lamellar keratitis related to endotoxins released from sterilizer reservoir biofilms. Ophthalmology. 2000;107(7):1227-1233.

6. Shah MN, Misra M, Wihelmus KR, Koch DD. Diffuse lamellar keratitis associated with epithelial defects after laser in situ keratomileusis. J Cataract Refract Surg. 2000;26(9):1312-1318.

7. Kaufman SC. Post-LASIK interface keratitis, Sands of the Sahara syndrome, and microkeratome blades. J Cataract Refract Surg. 1999 25(5):603-604.

8. Boorstein SM, Henk HJ, Elner VM. Atopy: a patient-specific risk factor for diffuse lamellar keratitis. Ophthalmology. 2003;110(1):131-137.

9. Hadden OB, McGhee CN, Morris AT, Gray TB, Ring CP, Watson AS. Outbreak of diffuse lamellar keratitis caused by marking-pen toxicity. J Cataract Refract Surg. 2008;34(7):1121-1124.

10. Shen YC, Wang CY, Fong SC, Tsai HY, Lee YF. Diffuse lamellar keratitis induced by toxic chemicals after laser in situ keratomileusis. $J$ Cataract Refract Surg. 2006;32(7):1146-1150.

11. Fogla R, Rao SK, Padmanabhan P. Diffuse lamellar keratitis: are meibomian secretions responsible? J Cataract Refract Surg. 2001;27(4) 493-495.

12. Schwartz GS, Park DH, Schloff S, Lane SS. Traumatic flap displacement and subsequent diffuse lamellar keratitis after laser in situ keratomileusis. J Cataract Refract Surg. 2001;27(5):781-783.

13. Linebarger EJ, Hardten DR, Lindstrom RL. Diffuse lamellar keratitis: diagnosis and management. J Cataract Refract Surg. 2000;26(7): 1072-1077.

14. Sutton G, Hodge C. Accuracy and precision of LASIK flap thickness using the IntraLase femtosecond laser in 1000 consecutive cases. J Refract Surg. 2008;24(8):802-806.

15. Ahn H, Kim JK, Kim CK, et al. Comparison of laser in situ keratomileusis flaps created by 3 femtosecond lasers and a microkeratome. J Cataract Refract Surg. 2011;37(2):349-357.

16. Sarayba MA, Ignacio TS, Tran DB, Binder PS. A $60 \mathrm{kHz}$ IntraLase femtosecond laser creates a smoother LASIK stromal bed surface compared to a Zyoptix XP mechanical microkeratome in human donor eyes. J Refract Surg. 2007;23(4)331-337.

17. Moshirfar M, Gardiner JP, Schliesser JA, et al. Laser in situ keratomileusis flap complications using mechanical microkeratome versus femtosecond laser: retrospective comparison. J Cataract Refract Surg. 2010;36(11):1925-1933.
18. Gil-Cazorla R, Teus MA, de Benito-Llopis L, Fuentes I. Incidence of diffuse lamellar keratitis after laser in situ keratomileusis associated with the IntraLase $15 \mathrm{kHz}$ femtosecond laser and Moria M2 microkeratome. $J$ Cataract Refract Surg. 2008;34(1):28-31.

19. Salomão MQ, Ambrósio R Jr, Wilson SE, Salomão MQ, Ambrósio R Jr, Wilson SE. Dry eye associated with laser in situ keratomileusis: Mechanical microkeratome versus femtosecond laser. J Cataract Refract Surg. 2009;35(10):1756-1760.

20. Lichter H, Stulting RD, Waring GO 3rd, Russell GE, Carr J. Buttonholes during LASIK: etiology and outcome. J Refract Surg. 2007;23(5): $472-476$.

21. Tomita M, Watabe M, Nakamura T, Nakamura N, Tsuru T, Waring GO 4th. Management and outcomes of suction loss during LASIK flap creation with a femtosecond laser. J Refract Surg. 2012; 28(1):32-36.

22. Durrie DS, Kezirian GM. Femtosecond laser versus mechanical keratome flaps in wavefront-guided laser in situ keratomileusis: prospective contralateral eye study. J Cataract Refract Surg. 2005; 31(1):120-126.

23. de Medeiros FW, Kaur H, Agrawal V, et al. Effect of femtosecond laser energy level on corneal stromal cell death and inflammation. J Refract Surg. 2009;25(10):869-874.

24. Bamba S, Rocha KM, Ramos-Esteban JC, Krueger RR. Incidence of rainbow glare after laser in situ keratomileusis flap creation with a $60 \mathrm{kHz}$ femtosecond laser. J Cataract Refract Surg. 2009;35(6):1082-1086.

25. Stonecipher KG, Dishler JG, Ignacio TS, Binder PS. Transient light sensitivity after femtosecond laser flap creation: clinical findings and management. J Cataract Refract Surg. 2006;32(1):91-94.

26. Binder PS. Flap dimensions created with the IntraLase FS laser. J Cataract Refract Surg. 2004;30(1):26-32.

27. Lubatschowski H. Overview of commercially available femtosecond lasers in refractive surgery. J Refract Surg. 2008;24(1):S102-S107.

28. Vryghem JC, Devogelaere T, Stodulka P. Efficacy, safety, and flap dimensions of a new femtosecond laser for laser in situ keratomileusis. $J$ Cataract Refract Surg. 2010;36(3):442-448.

29. Rosa AM, Neto Murta J, Quadrado MJ, et al. Femtosecond laser versus mechanical microkeratomes for flap creation in laser in situ keratomileusis and effect of postoperative measurement interval on estimated femtosecond flap thickness. J Cataract Refract Surg. 2009; 35(5):833-838.

30. Tomita M, Chiba A, Matsuda J, Nawa Y. Evaluation of LASIK Treatment with the Femto LDV in patients with corneal opacity. $J$ Refract Surg. 2012;28(1):25-30.
Clinical Ophthalmology

\section{Publish your work in this journal}

Clinical Ophthalmology is an international, peer-reviewed journal covering all subspecialties within ophthalmology. Key topics include: Optometry; Visual science; Pharmacology and drug therapy in eye diseases; Basic Sciences; Primary and Secondary eye care; Patient Safety and Quality of Care Improvements. This journal is indexed on Submit your manuscript here: http://www.dovepress.com/clinical-ophthalmology-journal

\section{Dovepress}

PubMed Central and CAS, and is the official journal of The Society of Clinical Ophthalmology (SCO). The manuscript management system is completely online and includes a very quick and fair peer-review system, which is all easy to use. Visit http://www.dovepress.com/ testimonials.php to read real quotes from published authors. 